\title{
Awareness and Application of Existing Agroecological Practices by Small Holder Farmers in Mvomero and Masasi Districts-Tanzania
}

\author{
John Constantine ${ }^{1}$, Kallunde P. Sibuga ${ }^{1}$, Mawazo J. Shitindi ${ }^{2} \&$ Angelika Hilberk $^{3}$ \\ ${ }^{1}$ Department of Crop Science and Horticulture, Sokoine University of Agriculture, Morogoro, Tanzania \\ ${ }^{2}$ Department of Soil and Geological Sciences, Sokoine University of Agriculture, Morogoro, Tanzania \\ ${ }^{3}$ University of Zurich, Switzerland \\ Correspondence: John Constantine, Department of Crop Science and Horticulture, Sokoine University of \\ Agriculture, Morogoro, Tanzania. Tel: 255-753-335-997. E- mail: kimariojc16@yahoo.com
}

Received: September 29, 2020

Accepted: November 9, 2020

Online Published: December 15, 2020

doi:10.5539/jas.v13n1p30

URL: https://doi.org/10.5539/jas.v13n1p30

The research is financed by SWISS AID Tanzania under Agroecology Project TA2/17/04.

\begin{abstract}
A survey study was conducted to assess the level of awareness and application of existing agro-ecological practices by small holder farmers in Mvomero and Masasi districts in Tanzania. The selection of farmers to interview and the villages in the respective districts was based on their long history of producing cassava and maize. A structured questionnaire was used to identify the type of agro-ecological practices, agricultural information sources accessed by farmers, training on agro-ecological practices, type of crops grown in the study areas and kind of livestock kept. Results indicated that the most applied agro-ecological practices were diversification $(80.5 \%)$, the use of farmer saved seeds $(78.2 \%)$ followed by intercropping $(72.9 \%)$ and lastly, agro-forestry (3.2\%). The highest percentage of farmers (30.4\%) reported to receive information on ecological organic agriculture from non-governmental organisations (NGOs) (SAT, SWISS AID), 27.5\% were using own farming experience, $21 \%$ reported to receive the information from government extension officers, $13 \%$ from friends or neighbours, $4.3 \%$ from government institutions (SUA, Agricultural Training Institutes) and 3.6\% received information from agricultural input suppliers. Generally, $50 \%$ of farmers had received training on agroecological practices indicating the level of awareness. Lack of knowledge among farmers was one of the key factors that hamper the wide application of agroecological practices. There was a need for farmer's capacity building through training to enhance wider application of agroecological practices hence progressive agricultural production increase.
\end{abstract}

Keywords: agroecology, agroecological practices, Manihot esculenta, Tanzania, Zea mays

\section{Introduction}

The application of agroecological practices in farming will ensure the sustainable production of enough food to feed the overwhelming global population increase which is estimated to be 9.1 billion by 2050 (Wezel, 2013). In Tanzania, maize (Zea mays L.) and cassava (Manihot esculenta Crantz.) are among the priority food crops grown by smallholder farmers contributing about $51 \%$ and $19 \%$ of dietary calories respectively (USDA, 2015; URT, 2016). However, current yields of maize and cassava averaged at 1.3 (Rowhani et al., 2011) and 8 metric tons per hector $\left(\mathrm{t} \mathrm{ha}^{-1}\right)$, respectively are far below the potential yields of $4-5 \mathrm{t} \mathrm{ha}^{-1}$ of maize (Barreiro-Hurle, 2012), and 20 metric tons per hectare $\left(\mathrm{t} \mathrm{ha}^{-1}\right)$ of cassava (TIC, 2018). Due to the importance of maize and cassava as priority crops for food security, several conventional measures have been undertaken to improve their productivity with limited success to resource poor farmers (Mkonda \& He, 2018). This is due to among other factors limited availability and high cost of industrial inputs including fertilizers and pesticides (Ngowi et al., 2007; Shekifu, 2011; Borrelli et al., 2020). As a result, most small holder farmers in Tanzania continue to rely on their traditional low cost practices especially in soil fertility and pest management (Backwell-Stone et al., 2008). According to Borrelli et al. (2020), the average synthetic fertilizer use in Tanzania is very low around $1 \mathrm{~kg} \mathrm{ha}^{-1}$ year compared to the world average of $1000 \mathrm{~kg} \mathrm{ha}^{-1}$ year $^{-1}$. In addition to high cost of industrial inputs (fertilizers and pesticides), there has been a concern on conventional methods of agricultural production due to associated side 
effects in the environment and human health (Ngowi et al., 2007; Aktar et al., 2009). Different from conventional farming, agro-ecological farming approaches have been reported to increase food production per unit area while protecting the environment as well as restoring productivity of degraded agro-ecosystems (Gliessman, 2015). Agro-ecological farming improves soil conditions in favor of plant growth, particularly by improving soil organic matter content and enhancing activity of soil biota (de-Schutter, 2010). Agro-ecology refers to the application of ecological concepts and principles to the design and management of sustainable agro-ecosystems (Silici, 2014). According to Altieri (2002a) and Silici (2014), ecological principles are: (i) enhancing the recycling of biomass with a view to optimize nutrient availability, (2) minimizing the use of external and non-renewable farm inputs, (3) minimizing losses due to flows of solar radiation, air, and water through increased soil cover, (4) diversifying species and genetic variety of the agro-ecosystem in time and space, and (5) enhancing beneficial biological interactions and synergies among the components of agro-biodiversity, thereby promoting key ecological processes and services. Farming practices (intercropping, mulching, use of cover crops, agro-forestry, integration of landscape into agriculture fields, organic soil fertilization, the use of natural pesticides, crop rotation) based on ecological principles are referred to as agro-ecological practices (Wezel, 2009; Amekawa et al., 2010).

Compared to developed countries, the agriculture sector in Tanzania is less developed (Rowhani et al., 2011) and is mainly dominated by small holder farmers with a total of 23732 ha of land suitable for ecological Agriculture (IFOAM, 2007). Though small holder farmers contribute about $69 \%$ of food produce in Tanzania (FAO, 2015), still low input ecological agriculture (agro-ecology) has not yet received sufficient attention. Agro-ecological technologies used by smallholder farmers are sparsely documented (IFAD, 2011; Bakengesa \& Uisso, 2015) and there is generally scant information on farmers' awareness and application of agro-ecological practices. Previous studies by Miyashita (2015) and Mdee et al. (2017) assessed the application of agro-ecological practices by small holder farmers in the Uluguru Mountains and surrounding low land areas. However the area covered in these studies was only limited to some parts of Morogoro region and therefore could not give a general picture of the application of Agro-ecological practices in the region and Tanzania at large. This study was therefore conducted to generate more information on the application of such practices by small holders in Mvomero and Masasi Districts of Tanzania. Specifically, the study aimed at establishing the status of farmer's knowledge and application of the agro-ecological practices for improved cassava and maize production.

\section{Methods}

\subsection{Description of the Study Sites}

This study was conducted in Mvomero and Masasi districts of Morogoro and Mtwara Regions, respectively in Tanzania between September and October, 2019. The two research sites represent areas with different agro ecological conditions. Mvomero district is located between $6^{\circ} 18^{\prime} 4^{\prime \prime} \mathrm{S}$ to $7^{\circ} 2^{\prime} 0^{\prime \prime} \mathrm{S}$ and $37^{\circ} 26^{\prime} 38^{\prime \prime} \mathrm{E}$ to $37^{\circ} 34^{\prime} 0^{\prime \prime} \mathrm{E}$. The district lies as low as 508 to as high as 1669 metres above sea level (m.a.s.l.) of which the low land areas have semi arid characteristics. The average annual temperature is $25.0^{\circ} \mathrm{C}$ in Mvomero while the average annual rainfall is $975 \mathrm{~mm}$. Soils in Mvomero district vary with topography. The hilly and mountainous areas are dominated by oxisols while valleys and low lands are characterized by alluvial soils. Grass lands and wood lands are dominated by sandy and clay soils (Hashimu et al., 2018).

On the other hand, Masasi is one of the six districts of Mtwara Region. Temperature in Masasi ranges between $24{ }^{\circ} \mathrm{C}$ and $27.5^{\circ} \mathrm{C}$ with the lowest being in June and highest in December. The district receives a uni-modal and erratic annual precipitation of $538 \mathrm{~mm}$ in dry years and $1550 \mathrm{~mm}$ in wet years but average annual precipitation is $873 \mathrm{~mm}$ (Dondeyne et al., 2003). Masasi District is located between $10^{\circ} 31^{\prime} 0^{\prime \prime} \mathrm{S}, 11^{\circ} 2^{\prime} 0^{\prime \prime} \mathrm{S}$ and $38^{\circ} 40^{\prime} 0^{\prime \prime} \mathrm{E}$, $39^{\circ} 12^{\prime} 0^{\prime \prime} \mathrm{E}$. The district lies as low as 271-293 m.a.s.l. in the semi arid-Southern coastal zone. With exception of soils found on the slopes which are less weathered, shallow and coarse textured, soils in other areas are characteristically deep, highly weathered, red sandy clay loam or sandy clay classified as Veti-Acric Ferralsols-Rhodic (Dondeyne et al., 2003). Mvomero is located in much drier inland region in the eastern zone of Tanzania, while Masasi is located approximately $200 \mathrm{~km}$ inland of coastal lowland in the southern zone of Tanzania. In these districts there are low altitude areas where cassava and maize are among the main produced staple food crops but with serious limitations of plant nutrients and prevalence of diseases and insect pests. 


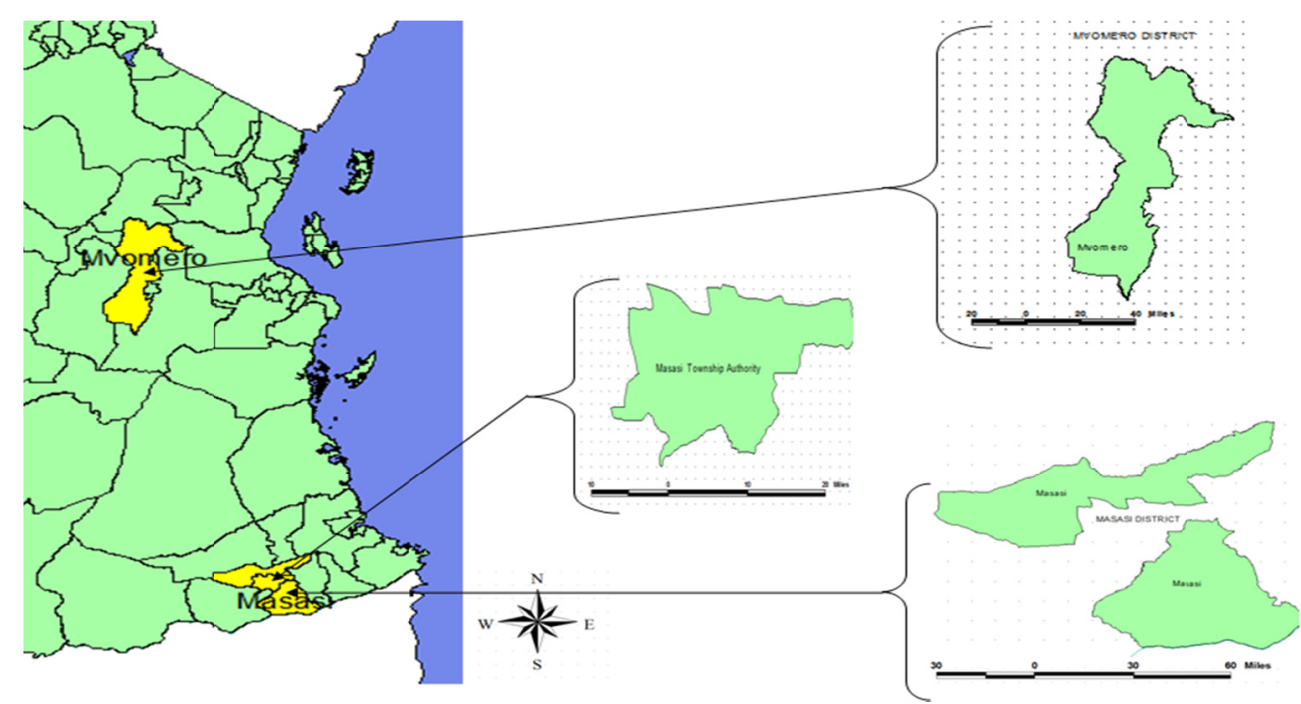

Figure 1. Section of the Map of Tanzania showing the location of Mvomero and Masasi Districts

\subsection{Sample Selection}

Multistage sampling technique was employed in this study (Akudugu et al., 2012). The first stage was purposive selection of the wards and villages and secondly, simple random sampling of the representative farmers within these wards and villages. In Mvomero district, sample farmers were interviewed from four divisions (Mgeta, Mlali, Mvomero and Turiani). In each division, fifteen (15) farmers were interviewed from two different wards and from two different villages. In Masasi district, sample farmers were interviewed from six divisions (Lulindi, Mchauru, Chiungutwa, Lisekese, Masasi and Chikundi). From each division at least thirteen (13) farmers were interviewed from two different wards, including one village per ward. Total population and estimated number of farmers per district were as presented in Table 1. The sample size (number of farmers interviewed) was determined using equation No. 1 as proposed by Wonnacott and Wonnacott (1990) (as cited in Hashim et al., 2018).

$$
n=\frac{Z^{2} p(1-p)}{Q^{2}}
$$

Where, $n=$ required sample size, $z=$ confidence level at $95 \%$ (standard value of 1.96), $p=$ percentage of farmers in population estimated at $90 \%$ and $Q=$ margin of error at $5 \%$ (standard value of 0.05 ). Hence, the number of farmers interviewed was determined as shown below:

$$
n=\frac{Z^{2} p(1-p)}{Q^{2}}=\frac{(1.96)^{2}(0.9)(1-0.9)}{(0.05)^{2}}=138.2976 \approx 138
$$

A total of one hundred thirty eight (138) farmers in 20 villages were interviewed; seventy nine (79) from Masasi and fifty nine (59) from Mvomero. Selection of the wards and villages in both Masasi and Mvomero districts was based on long history of producing cassava and maize for the past 30 years.

Table 1. Sample size for interview in each study areas

\begin{tabular}{lllllll}
\hline District & $\begin{array}{l}\text { District Population size } \\
\text { (Census, 2012) }\end{array}$ & $\begin{array}{l}90 \% \text { of the district } \\
\text { total population }\end{array}$ & $\begin{array}{l}90 \% \text { of district } / 90 \% \text { of } \\
\text { total population } \times 100\end{array}$ & $\begin{array}{l}\text { Percentage sample } \\
\text { size per district }\end{array}$ & Total sample size & $\begin{array}{l}\text { Sample size } \\
\text { per district }\end{array}$ \\
\hline Masasi & 350689 & 315620 & $315620 / 550093 \times 100$ & 57 & 138 & 79 \\
Mvomero & 260525 & 234473 & $234473 / 550093 \times 100$ & 43 & & 59 \\
Total & 611214 & 550093 & & 100 & 138 \\
\hline
\end{tabular}

\subsection{Data Collection}

Quantitative and qualitative data were collected through face to face interviews using a structured questionnaire and the use of GPS for location data. Data was collected on geographical location and topography of the study 
area, farmer's social economic information (age, sex and gender), type of crops grown and average yield, agro-ecological practices applied by farmers and type and numbers of livestock kept by farmers.

\subsection{Data Analysis}

Analyses were done using the Statistical Package for Social Sciences (SPSS) software for windows version 24.0 (IBM Corp, 2016). Descriptive statistics (frequencies, means percentages and cross tabulation) were used in order to generate descriptions from the data collected. To make statistical inferences, contingency chi-square tests were computed at $\mathrm{P} \leq 0.05$ levels of significance to establish relationships between variables.

\section{Results}

\subsection{Farmers Demographic Characteristics and Duration of Stay in the Study Areas}

This study indicated that there was no significant difference $(\mathrm{P}>0.05)$ among respondent's social demographic characteristics across the two study districts (Table 2). Out of 138 respondents, $57.2 \%$ were male and $42.8 \%$ were female (Table 2). The majority of respondents were between the ages of 46 and 60 years (42.8\%). Out of the total number of interviewed farmers, $8 \%$ had not received any formal education, $85.5 \%$ had primary level of education, $5.8 \%$ had secondary school education and only $1 \%$ had more than secondary school education. The duration of stay of farmers in their respective villages ranged from 2 to 66 years and the mean duration was 34.12 years. However, there was no significant difference $\left(\chi^{2}=1.53\right.$; d.f. $\left.=3 ; \mathrm{P}=0.675\right)$ in farmers farming experience in Mvomero and Masasi (Table 2). Results also indicated that majority of farmers $(50 \%)$ had farm size less than 2 hectares for both hired and owned.

Table 2. Demographic characteristics of farmers in the two districts used in this study

\begin{tabular}{|c|c|c|c|c|c|c|c|}
\hline \multirow{2}{*}{\multicolumn{2}{|c|}{ Characteristic of respondent }} & \multicolumn{2}{|c|}{ Study areas } & \multirow{3}{*}{$\begin{array}{l}\text { Mean } \\
8.7\end{array}$} & \multirow{3}{*}{$\begin{array}{l}\chi^{2} \\
0.575\end{array}$} & \multirow{3}{*}{$\begin{array}{l}\text { d.f. } \\
3\end{array}$} & \multirow{3}{*}{$\begin{array}{l}\text { P-value } \\
0.902\end{array}$} \\
\hline & & \multirow{2}{*}{$\begin{array}{l}\text { Mvomero }(\%)(n=59) \\
6.8\end{array}$} & \multirow{2}{*}{$\begin{array}{l}\text { Masasi }(\%)(n=79) \\
10.1\end{array}$} & & & & \\
\hline \multirow{5}{*}{ Age } & Below 30 & & & & & & \\
\hline & $31-45$ & 37.3 & 38 & 37.7 & & & \\
\hline & $46-60$ & 44.1 & 41.8 & 42.8 & & & \\
\hline & 61 and above & 11.9 & 10.1 & 10.9 & & & \\
\hline & Total & 100 & 100 & 100 & & & \\
\hline \multirow{3}{*}{ Gender } & Male & 52.5 & 60.8 & 57.2 & 0.932 & 1 & 0.334 \\
\hline & Female & 47.5 & 39.2 & 42.8 & & & \\
\hline & Total & 100 & 100 & 100 & & & \\
\hline \multirow{5}{*}{ Education } & No formal education & 6.8 & 8.9 & 8 & 4.359 & 3 & 0.225 \\
\hline & Primary & 91.5 & 81 & 85.5 & & & \\
\hline & Secondary & 1.7 & 8.9 & 5.8 & & & \\
\hline & Tertiary & 0 & 1.3 & 0.7 & & & \\
\hline & Total & 100 & 100 & 100 & & & \\
\hline \multirow{5}{*}{ Duration of stay (years) } & Below 10 & 10.2 & 11.4 & 10.9 & 1.53 & 3 & 0.675 \\
\hline & Nov-20 & 16.9 & 11.4 & 13.8 & & & \\
\hline & $21-30$ & 15.3 & 21.5 & 18.8 & & & \\
\hline & $\geq 31$ & 57.6 & 55.7 & 56.5 & & & \\
\hline & Total & 100 & 100 & 100 & & & \\
\hline \multirow{5}{*}{ Farm size (hectors) } & Below 2 & 52.5 & 48.1 & 50 & 3.573 & 3 & 0.311 \\
\hline & $2.4-4$ & 27.1 & 34.2 & 31.2 & & & \\
\hline & $4.4-6$ & 5.1 & 10.1 & 8 & & & \\
\hline & 6.4 and above & 15.3 & 7.6 & 10.9 & & & \\
\hline & Total & 100 & 100 & 100 & & & \\
\hline
\end{tabular}

Note. $\mathrm{df}=$ degree of freedom, $\chi^{2}=$ Chi-Square test, $\mathrm{P} \leq 0.05$ indicates there was a significant difference. 


\subsection{Influence of Farmers' Demographic Characteristics on Application of Agroecological Practices}

There were influences of some farmers' demographic characteristics on application of some agroecological practices. For instance, there was significant influence $\left(\chi^{2}=10.664\right.$; d.f. $\left.=3 ; \mathrm{P}=0.022\right)$ of farm size on application of poultry manure and crop and livestock integration. Similarly, there was significant relationship between farmers' education level and the use of cover crops $\left(\chi^{2}=9.346\right.$; d.f. $\left.=3 ; \mathrm{P}=0.025\right)$ and agro-forestry $\left(\chi^{2}=14.85 ;\right.$ d.f. $=3 ; \mathrm{P}$ $=0.022$ ). However there was no significant influence of farmers' gender on application of any of the agroecological practices.

3.3 Application of Agroecological Practices, Training and Sources of Agricultural Information Accessed by Farmers

The most applied agro-ecological practices by farmers were diversification, the use of farmers saved seeds and intercropping (Table 3). However the least applied agro-ecological practice was agro-forestry.

Table 3. Application of agroecological practices by trained and non trained farmers

\begin{tabular}{llll}
\hline \multirow{2}{*}{ Agroecological practice } & \multicolumn{2}{c}{ Study areas } & Mean $(\%)$ \\
\cline { 2 - 3 } & Mvomero (\%) $(\mathrm{n}=59)$ & Masasi (\%) $(\mathrm{n}=79)$ & 72.9 \\
\hline Intercropping & 50.8 & 94.9 & 27.1 \\
Mulching & 23.7 & 30.4 & 19.4 \\
Use of cover crops & 18.6 & 20.3 & 3.2 \\
Agroforestry & 5.1 & 1.3 & 29.8 \\
Use of cattle manure & 30.5 & 29.1 & 23.5 \\
Use of compost & 20.3 & 26.6 & 45.0 \\
Use of poultry manure & 45.8 & 44.3 & 7.6 \\
Use of pig manure & 15.3 & 0.0 & 21.1 \\
Use of goat manure & 22.0 & 20.3 & 13.1 \\
Green manure & 18.6 & 7.6 & 80.5 \\
Diversification & 71.2 & 89.9 & 53.3 \\
Crop and livestock integration & 50.8 & 55.7 & 39.5 \\
Organic pest management & 32.2 & 46.8 & 78.2 \\
Use of farmer saved seeds & 78.0 & 78.5 & 25.6 \\
Fallowing & 27.1 & 24.1 & 43.5 \\
Crop rotation & 33.9 & 53.2 & 37.6 \\
Use of ant erosion measures & 42.4 & 32.9 & \\
\hline
\end{tabular}

There was no significant difference (Figure 2) between the number of trained and non trained farmers across the two districts $\left(\chi^{2}=0.266\right.$; d.f. $\left.=1 ; \mathrm{P}=0.606\right)$. Half of farmers in the two study areas have had received training on agroecological practices. It was also shown that there was strong significant difference $\left(\chi^{2}=72.157\right.$; d.f. $=37 ; \mathrm{P}=$ 0.000 ) on farmers sources of information across the two study districts (Table 4). The major sources of information were from NGOs, the use of farmers own experience followed by Government extension services.

Table 4. Sources of information on agroecological farming

\begin{tabular}{llllll}
\hline Source of information & Frequency & Percent & $\chi^{2}$ & d.f. & P-value \\
\hline NGOs (SAT, SWISSAID) & 42 & 30.4 & & & \\
Input suppliers & 5 & 3.6 & & & \\
Government extension officers & 29 & 21 & & & \\
Farmers own experience & 38 & 27.5 & 72.157 & 37 & 0.000 \\
SUA/ARIs & 6 & 4.3 & & & \\
Friends or neighbours & 18 & 13 & & & \\
Total & 138 & 100 & & & \\
\hline
\end{tabular}

Note. d.f. $=$ degree of freedom, $\chi^{2}=$ Chi-Square test, $\mathrm{P} \leq 0.05$ indicates there was a significant difference. 
Compared with farmers who reported to have received training on agro-ecological practices, who to a large extent (Figure 3) apply the practices, few non- trained farmers apply the practices (Table 5). Example while $91.3 \%$ of farmers who received training apply intercropping only $42 \%$ of farmers who did not receive training practice intercropping. Results also indicated that none of the farmers apply integration of elements of landscape into agricultural fields. Similarly, agro-forestry is also poorly integrated by only $3.2 \%$ of farmers. Results indicated that trained farmers who practice fallowing are less than $40 \%$ (Figure 3) while for non trained farmers was only $11.6 \%$ (Table 5).

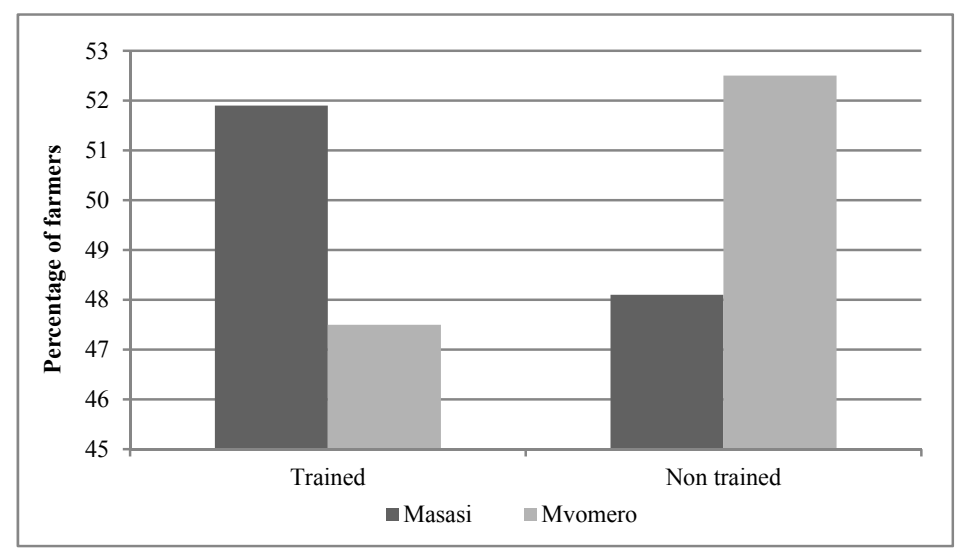

Figure 2. Status of farmers training on Agroecological practices $\left(\chi^{2}=0.2 .66 ;\right.$ d.f. $\left.=1 ; P=0.606\right)$

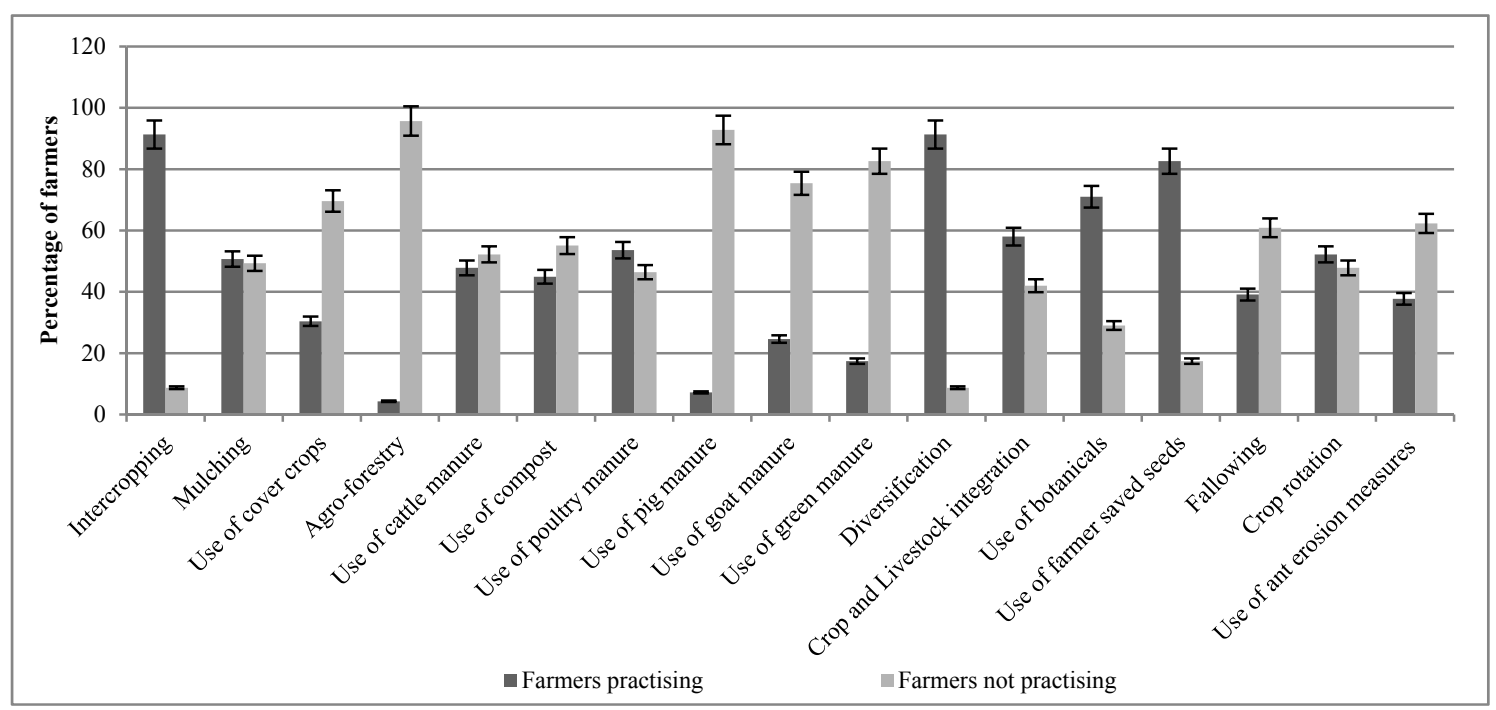

Figure 3. Agroecological practices applied by trained farmer 
Table 5. Application of agroecological practices by non-trained farmers

\begin{tabular}{|c|c|c|c|c|}
\hline \multirow{2}{*}{ Practice } & \multicolumn{2}{|c|}{ Farmers practicing $(\mathrm{n}=69)$} & \multicolumn{2}{|c|}{ Farmers not practicing $(\mathrm{n}=69$} \\
\hline & Frequency & Percentage & Frequency & Percentage \\
\hline Intercropping & 42 & 60.9 & 27 & 39.1 \\
\hline Mulching & 3 & 4.3 & 66 & 95.7 \\
\hline Use of cover crops & 6 & 8.7 & 63 & 91.3 \\
\hline Agro-forestry & 1 & 1.4 & 68 & 98.6 \\
\hline Integration of landscape into Agriculture fields & 0 & 0.0 & 69 & 100 \\
\hline Use of cattle manure & 8 & 11.6 & 61 & 88.4 \\
\hline Use of compost & 2 & 2.9 & 67 & 97.1 \\
\hline Use of poultry manure & 25 & 36.2 & 44 & 63.8 \\
\hline Use of pig manure & 4 & 5.8 & 65 & 94.2 \\
\hline Use of goat manure & 12 & 17.4 & 57 & 82.6 \\
\hline Use of green manure & 5 & 7.2 & 64 & 92.8 \\
\hline Diversification & 50 & 72.5 & 19 & 27.5 \\
\hline Crop and Livestock integration & 34 & 49.3 & 35 & 50.7 \\
\hline Organic pest management (use of botanicals) & 7 & 10.1 & 62 & 89.9 \\
\hline Use of peasant seeds & 51 & 73.9 & 18 & 26.1 \\
\hline Fallowing & 8 & 11.6 & 61 & 88.4 \\
\hline Crop rotation & 26 & 37.7 & 43 & 62.3 \\
\hline Use of ant- erosion measures (stone barriers and grass strips) & 25 & 36.2 & 44 & 63.8 \\
\hline
\end{tabular}

\subsection{Number of Animals Kept and Crops Grown by Farmers}

Results in Table 6 indicated that with exception of chicken which were found to be kept by more than 50 percent of farmers in the two districts, the rest of the animal categories were kept by less than $50 \%$ of farmers of which only 10.2 and $2.5 \%$ were keeping cattle for Mvomero and Masasi respectively.

Table 6. Proportion of farmers keeping animals in Mvomero and Masasi Districts

\begin{tabular}{lll}
\hline \multirow{2}{*}{ Animal category } & \multicolumn{2}{c}{ Percentage of farmers } \\
\cline { 2 - 3 } & Mvomero $(\mathrm{n}=59)$ & Masasi $(\mathrm{n}=79)$ \\
\hline Cattle & 10.2 & 2.5 \\
Pigs & 10.2 & 1.3 \\
Sheep & 1.7 & 0 \\
Goats & 25.4 & 26.6 \\
Rabbits & 5.1 & 1.3 \\
Chicken & 71.2 & 72.2 \\
Ducks & 5.1 & 12.7 \\
\hline
\end{tabular}

Results also showed that, farmers produce assortment of food crops (Table 7) indicating that individuals from the study areas had different sources of food and therefore dietary diversity and thus nutrition. This study has also indicated that maize was the most cultivated staple food crop (88.4\%) followed by cassava (24.6\%). In the study areas velvet bean (Mucuna prurience) was grown by low percentage of farmers despite its potential as a food and a cover crop. 
Table 7. Crops grown by farmers in Mvomero and Masasi study areas (Multiple responses)

\begin{tabular}{|c|c|c|c|c|c|c|}
\hline \multirow{2}{*}{ Crop type } & \multicolumn{2}{|c|}{ Percentage of respondents } & \multirow{2}{*}{ Mean } & \multirow{2}{*}{$\chi^{2}$} & \multirow{2}{*}{ d.f. } & \multirow{2}{*}{ P-value } \\
\hline & Mvomero $(\mathrm{n}=59)$ & Masasi $(\mathrm{n}=79)$ & & & & \\
\hline Maize & 84.7 & 97.5 & 87.9 & 7.453 & 1 & 0.006 \\
\hline Cassava & 18.6 & 46.8 & 32.7 & 11.833 & 1 & 0.001 \\
\hline Millet & 1.7 & 3.8 & 2.75 & 0.531 & 1 & 0.466 \\
\hline Sunflower & 25.4 & 27.8 & 26.6 & 0.101 & 1 & 0.750 \\
\hline Simsim & 1.7 & 31.6 & 16.6 & 19.814 & 1 & 0.000 \\
\hline Pigeon pea & 16.9 & 69.6 & 43.25 & 37.607 & 1 & 0.000 \\
\hline Cowpea & 20.3 & 22.8 & 21.5 & 0.119 & 1 & 0.730 \\
\hline Green gram & 3.4 & 36.7 & 20.05 & 21.528 & 1 & 0.000 \\
\hline Groundnuts & 0.0 & 38 & 19 & 28.629 & 1 & 0.000 \\
\hline Cashew nuts & 0.0 & 30.4 & 15.2 & 21.698 & 1 & 0.000 \\
\hline Cocoa & 11.9 & 0.0 & 5.95 & 6.947 & 1 & 0.008 \\
\hline Rice & 32.2 & 8.9 & 20.55 & 12.036 & 1 & 0.001 \\
\hline Bambara nuts & 0.0 & 17.7. & 8.85 & 11.636 & 1 & 0.001 \\
\hline Velvet bean & 0.0 & 2.5 & 1.25 & 1.516 & 1 & 0.218 \\
\hline
\end{tabular}

Note. d.f. $=$ degree of freedom, $\chi^{2}=$ Chi-Square test, $\mathrm{P} \leq 0.05$ indicates there was a significant difference.

\section{Discussions}

Farmer's demographic characteristics have influence on the adoption of agricultural technologies. There were influences of some farmers' demographic characteristics on application of some agroecological practices. For instance, there was significant influence of farm size on application of poultry manure and crop and livestock integration. Farmers with small size farms were the one who were likely to apply poultry manure than farmers with relatively large farms due to limited amount of manure obtained from poultry.This supports the work by Williams (1999) who also reported that there was a relationship between the proportion of land cultivated by the farmer and the application of organic fertilizers. Similarly, there was significant relationship between farmers' education level and the use of cover crops and agro-forestry. This study has indicated that the more educated the farmers are, the more they learn, experiment and ultimately willing to adopt new agricultural farming practices as was also reported by Gomarasca ( 2012) and Muchangi (2016). A study by Azam (2015) reported the influence of farmers' education status, gender and extension contacts on adoption of ecological farming practices. On the other hand, there was no significant influence of farmers' gender on application of any of the agroecological practices. During the survey, almost equal number of men and women were involved in the interview implying that, outcomes of this study represent collective views and opinions of both men and women regarding the application of agroecological practices in agriculture production. The highest percentage of farmers falling between 46 to 60 years indicates that most of the respondents in the two districts belong to the energetically active age group who would improve the productivity of agriculture upon application of the agroecological practices. The composition of farmers interviewed that included non educated to post secondary education implies that these findings are representative of both literate and illiterate farmers of the Masasi and Mvomero districts on the application of agroecological practices. The duration of stay of farmers in their respective villages ranged from 2 to 66 years and the mean duration was 34.12 years indicating that the population had experience in maize and cassava production. The majority of farmers had farm size less than 2 hectors while only few (10.6\%) had land size of 6 and above hectors indicating that, there is a great possibility of adoption of agroecological practices as most of the farmers are small scale farmers. These results agrees with those reported by Akudugu et al. (2012) that small scale farmers are likely to adopt new technologies as small farms are flexible in accommodating new changes compared to the large farms.

Half of farmers in the two study areas have had received training on agroecological practices. This has been attributed to a large extent by the fact that the two major activists of agro-ecology (SAT and SWISSAID) are operating in the two study districts. While farmers indicated to receive information on ecological agriculture from different sources however the majority of farmers indicated to have been receiving the information from NGOs. This has been attributed to the fact that NGOs as opposed to government extension services are more backed up, have short lines of communication and are therefore flexible enough in responding to farmers needs in short time. Furthermore, the innovative dissemination methods developed by SWISSAID and SAT through farmer to farmer 
contact and in both groups and as individuals have enabled them to be more successful in reaching more farmers. These findings are consistent with those reported by Bonabana (2002) and Udimal et al. (2017). Diversified sources of agricultural information enable farmers to get different experience from different sources. These results agree by tho se reported by Wanyama et al. (2015) and Yaseen et al. (2016).

Some agroecological practices were applied only by a small number of farmers. This could be attributed to land ownership. Land ownership has influence on the managerial practices. Farmers who own land are likely to apply practices like agro-forestry, fallowing and integration of landscape into agriculture fields as they are sure of getting benefits for a long time as compared to hired land whereby farmers may not be willing to invest on practices that take relatively longer time to realize the benefits. These findings are in line with those repoted by Arellanes and Lee (2003) that land ownership has influence on adoption of a new agricultural technology.

The larger percentage of trained farmers who apply the practices implies that trained farmers are more likely to understand the basic concepts and practices of agro-ecology. They are more easily to shift to a more sustainable farming system and are more ready to take the risks associated with changing of production technologies as compared to non trained farmers. This agrees with the findings by Udimal et al. (2017) who reported that adoption of a technology depends on the information available about that techology to the expected adopters. Being aware of the advantages and disadvantages of ecological farming, farmers who acquired that knowledge are likely to shift away from conventional farming as compared to non trained farmers who are not aware of the side effects of conventional farming and consequently continue to rely on synthetic farm inputs. Hence as indicated in Table 6, agro-ecological farmers are the one who are likely to adopt and use agro-ecological practices than those who never received training indicating the level of illiteracy on ecological farming and associated human and environmental health benefits as supported also by the works of Mdee et al. (2018), Azam (2015) and Gomarasca (2012). In this case there is a need to extend trainings to succeed widespread application of agroecological practices. Meiyer et al. (2014) reported that, a technology can be adopted if farmers know how the technology works and what it can achieve. Furthermore, although this study has indicated that some of the farmers own cattle, sheep, goats and chicken still only some of them use manure for soil fertility amendments and this is ascribed to illiteracy. However according to this study, some of farmers in the study areas have been applying practices like intercropping, diversification, the use of farmer saved seeds and crop and livestock integration as a traditional routine but are also part of the agro-ecological set of practices.

The observed small percentage of farmers who apply agroforestry, intergration of landscape in agricultural fields and fallowing could also be associated with lack of knowledge on the benefits of the practices as well as lack of skills. This supports the study by Kabwe et al. (2009). Farmers could get a number of benefits through application of practices. For instance, agroforestry has several benefits including soil nitrogen improvement, source of livestock feed, source of materials for compost making, source of firewood, building materials and also they act as wind breakers. Agroforestry trees also help to make the soil firm to resist wind and water erosion. And also they make possible recycling of nutrients by bringing to the surface the nutrients that are deeper beyond the reach of crop roots. So to succeed adoption of agro-forestry requires research on the type of agro-forestry tree species that are adapted to the study areas followed by training to farmers on the type of trees that will be adapted to the local climatic conditions of their areas. This is in consistent with the work by Kabwe et al. (2009) who reported that, farmers may be willing to adopt a certain technology if they try it rather than if they dont try at all. Adoption of integration of elements of landscape practice would contribute to increased ecological processes like pollination and crop insect pest natural enemies and consequently improved ecosystem services like crop yields (Bengtsson, 2015). Wezel et al. (2013) reported that some of agro-ecological practices are still poorly integrated in actual agriculture farming including Agro-forestry, the use of bio-pesticides and integration of landscape. Small number of farmers who practice fallowing could also be ascribed to continuous decrease in arable land so farmers do not have alternative land for crop production during fallowing. This concurs with the findings reported by Franzel (1999). Feasible alternatives to fallowing can be employed like the application of practices that can restore the soil fertility quickly like application of farm yard manure, compost, intercropping, the use of green manure crops and agro-forestry to enhance nutrient recycling processes.

Results indicated that most of animal categories were kept by less than $10 \%$ of farmers. Majority of farmers keeping animals especially large animals like cattle would ensure availability of manure for soil fertility amendment. Low percentage of farmers who own pigs were associated with religious believes as most of the areas under this study are occupied by Muslims but could also be associated with social economic constraints. This calls for more promotion of alternatives to animal manure like compost, green manuring, and intercropping for soil fertility amendments. The results agree to a survey report by Jackson and Mtengeti (2005) in the southern highlands of Tanzania which indicated that $80 \%$ of farmers have had no access to manure to fertilize their fields. 
In both Masasi and Mvomero districts farmers produce various types of food crops as well as keeping animals indicating access of individuals to dietary diversity and thus nutrition. Dietary diversity is a qualitative measure of food consumption that reflects household access to assortment of foods and is also an indication for sufficient nutrient supply through the diet (FAO, 2019).

The dominance of cassava and maize in the two study districts shows the importance of the two crops as source of dietary calories as also reported by USDA (2015) and URT (2016). Apart from other food crops produced in the study areas, velvet bean (Mucuna prurience) is grown by low percentage of farmers despite its potential as a food and a cover crop. According to Buckles et al. (1998) and Nichollis and Altieri (2018), Mucuna can fix up to $150 \mathrm{~kg}$ $\mathrm{N} \mathrm{ha}^{-1}$ and can also help to suppress weeds by physically preventing them from growing or inhibiting their germination and emergence.

Generally, this study indicated that a good number of elements of agro-ecology outlined by FAO (2019) are well integrated by farmers in Mvomero and Masasi districts. Eight out of the ten elements of agro ecology have been well integrated. The elements of Agro-ecology are interlinked and mutually support each other. Farmers have shown to produce assortment of crops and livestock, practice that increases synergies in food systems through deliverance of multiple benefits. The intercropping practice shown by most of the farmers indicates high level of diversification. According to FAO (2019), diversified agroecological systems are more resilient, and they have a greater capacity to recover from perturbation and high capacity to withstand against insect pests and disease attack. The assortment of foods that are produced by farmers in the study areas indicates that farmers have got their own food preferences according to their traditions. Similarly there has been equal opportunity for both male and female on agroecological training to address gender inequality. Recycling practices like compost making and application has also been addressed in this study. The study has also indicated that the government has created environment for NGOs to operate in the study areas through training of farmers on agro-ecology indicating the responsible governance. The NGOs have also enabled farmers to be innovative and sharing of knowledge among each other.

\section{Conclusion and Recommendations}

This study has generally indicated that, the most applied agroecological practices across the study districts are diversification, the use of farmer saved seeds and intercropping. Some of agroecological practices (Agro-forestry and integration of elements of landscape into agricultural field) are still poorly adopted. Most farmers do not have access to farm yard manure due to low number of farmers who keep cattle . Alternative methods of ecological soil fertility management like the use of compost and intercropping should be promoted. Lastly, to succeed wide spread and application of agroecological practices farmers require more training programmes.

\section{Acknowledgements}

The authors of this work are very gratefully to the SWISS AID Tanzania for funding this study through Agroecology Project TA2/17/04. Thanks are also extended to farmers and Extension officers who participated in this study.

\section{References}

Aktar, W., Dwaipayan, S., \& Ashim, C. (2009). Impact of pesticides use in Agriculture: Their benefits and hazards. Journal of Interdisciplinary Toxicology, 2(1), 1-12. https://doi.org/10.2478/v10102-009-0001-7

Akudugu, M. A., Guo, E., \& Dadzie, S. K. (2012). Adoption of Modern Agricultural Production Technologies by Farm Households in Ghana: What Factors Influence their Decisions? Journal of Biology, Agriculture and Healthcare, 2(3), 2224-3208.

Altieri, M. A. (2002a). Agroecology: The science of natural resource management for poor farmers in marginal environments. Agriculture, Ecosystems and Environment, 93(1-3), 1-24. https://doi.org/10.1016/S0167-88 09(02)00085-3

Amekawa, Y., Sseguya, H., Onzere, S., \& Carranza, I. (2010). Delineating the multifunctional role of agro-ecological practices: Toward sustainable livelihoods for smallholder farmers in developing countries. Journal of Sustainable Agriculture, 34, 202-228. https://doi.org/10.1080/10440040903433079

Arellanes, P., \& Lee, D. R. (2003). The Determinants of Adoption of Sustainable Agriculture Technologies: Evidence From the Hillsides of Honduras. Proceedings of the 25th International Conference of Agricultural Economists (IAAE), Cornell University, Ithaca, NY, USA (pp. 693-699).

Azam, S. (2015). The Influence of Socio-Demographic Factors in adopting Organic Farming Practices. International Journal of Interdisciplinary and Multidisciplinary Studies, 2(5), 8-17. 
Bakengesa, S., \& Uisso, A. J. (2015). Organic Study Report on Agriculture Technologies in Tanzania (p. 35).

Bakewell-Stone, P., Geir, L., \& Charles, F. (2008). Potentials for organic agriculture to sustain livelihoods in Tanzania: International Journal of Agricultural Sustainability, 6(1), 22-36. https://doi.org/10.3763/ ijas. 2007.0266

Barreiro-Hurle, J. (2012). Analysis of incentives and disincentives for maize in the United Republic of Tanzania. Retrieved from http://www.fao.org/fileadmin

Bengtsson, J. (2015). Biological control as an ecosystem service: Partitioning contributions of nature and human inputs to yield. Ecological Entomology, 40, 45-55. https://doi.org/10.1111/een.12247

Bonabana, W. (2002). Assessing Factors Affecting Adoption of Agricultural Technologies: The Case of Integrated Pest Management (IPM) in Kumi District, Eastern Uganda (p. 146, Msc. dissertation, Virginia Polytechnic Institute, Virginia State University, USA).

Borrelli, N., Benegiamo, M., Mura, G., \& Razzano, C. C. (2020). Small Farmers and Sustainable Food System Transition: The Theoretical Framework (p. 106). Ledizioni Ledi, Milano, Italy.

Buckles, D., Triomphe, B., \& Sain, G. (1998). Cover Crops for Hillside Agriculture. Canada: IDRC. 230pp.

De Schutter, O. (2010). Report submitted by the Special Rapporteur on the right to food (p. 21). NY: United Nations Human Right Council.

Dondeyne, S., Ngatunga, E. L., Cools, N., Mugogo, S., \& Deckers, J. (2003). Landscapes and soils of South Eastern Tanzania: their suitability for cashew. In C. P. Topper \& L. J. Kasuga (Eds.), Knowledge transfer for sustainable tree crop development: A case history of the Tanzanian Integrated Cashew Management Programme (pp. 229-239). Bio Hydrids Agrisystems Ltd., Reading, UK.

FAO (Food and Agriculture Organization of the United Nations). (2015). The economic lives of smallholder farmers: An analysis based on household data from nine countries (p. 48). FAO, Rome, Italy.

FAO (Food and Agriculture Organization of the United Nations). (2019). The Ten Elements of Agroecology, guiding the transition to sustainable food and agricultural systems (p. 4). Conference paper, FAO.

Franzel, S. (1999). Socioeconomic factors affecting the adoption potential of improved tree fallows in Africa. Agroforestry Systems, 47(1), 305-321. https://doi.org/10.1023/A:1006292119954

Gliessman, S. R. (2015). Agroecology: The Ecology of Sustainable Food Systems (p. 386). Taylor and Francis Group, London. https://doi.org/10.1201/b17881

Gomarasca, M. (2012). Factors affecting the adoption of agroecological practices among private farmers in Villa Clara, Cuba (p. 95, Master's dissertation, Gent University, Belgium).

Hashim, I., Mamiro, D. P., Mabagala, R. B., \& Tefera, T. (2018). Smallholder Farmers' Knowledge, Perception and Management of Rice Blast Disease in Upland Rice Production in Tanzania. Journal of Agricultural Science, 10, 137-145. https://doi.org/10.5539/jas.v10n7p137

IBM (International Business Machines Corporation). (2016). IBM SPSS Statistics for Windows (24th ed.). IBM Corporation, Armonk, NY. Retrieved from https://www01.ibm.com/support/docview.wss?

IFOAM (International Federation of Organic Agriculture Movements). (2007). Annual Report (p. 28).

Jackson, H. L., \& Mtengeti, E. J. (2005). Assessment of animal manure production, management and utilization in Southern Highlands of Tanzania. Livestock Research for Rural Development, 17, 110. Retrieved from https://www.lrrd.org/lrrd17/10/jack17110.htm

Kabwe, G., Bigsby, H., \& Cullen, R. (2009). Factors influencing adoption of agroforestry among smallholder farmers in Zambia (p. 15). Paper presented at the 2009 NZARES Conference Tahuna Conference Centre, Nelson, New Zealand.

Mdee, A., Wostry, A., Coulson, A., \& Maro, J. (2018). A pathway to inclusive sustainable intensification in agriculture? Assessing evidence on the application of agroecology in Tanzania. Agroecology and Sustainable Food Systems, 43(2), 201-227. https://doi.org/10.1080/21683565.2018.1485126

Meiyer, S. S., Catacutan, D., Ajayi, O. C., Sileshi, G. W., \& Nieuwenhuis, M. (2014). The role of knowledge, attitudes and perceptions in the uptake of agricultural and agroforestry innovations among smallholder farmers in sub-Saharan Africa. International Journal of Agricultural Sustainability, 13(1), $40-54$. https://doi.org/10.1080/14735903.2014.912493 
Melesse, B. (2018). A Review on Factors Affecting Adoption of Agricultural New Technologies in Ethiopia. Journal of Agriculture Science and Food Research, 9, 226.

Miyashita, C. (2015). Can organic farming be an alternative to improve well-being of smallholder farmers in disadvantaged areas? A case study of Morogoro Region, Tanzania (p. 117, Unpublished MA dissertation in Rural Development, Sokoine University of Agriculture. Morogoro, Tanzania).

Mkonda, M. Y., \& He, X. (2018). Agricultural history nexus food security and policy framework in Tanzania. Agriculture and Food Security, 7, 75. https://doi.org/10.1186/s40066-018-0228-7

Muchangi, C. T. (2016). Influence of Farmer's Characteristics, Agricultural Extension and Technology Specific Factors on Adoption of Organic Farming Technologies in Embu West Sub County, Embu, Kenya (p. 83, Master's dissertation, University of Nairobi, Kenya).

Ngowi, A., Mbise, T., Ijani, A., London, L. A., \& Oluyede, O. (2007). Pesticides use by smallholder farmers in vegetable production in Northern Tanzania. Crop Protection, 26, 1617-1624. https://doi.org/10.1016/ j.cropro.2007.01.008

Nicholls, C. I., \& Altieri, M. A. (2018). Pathways for the amplification of agroecology. Agroecology and Sustainable Food Systems, 32, 1170-1193. https://doi.org/10.1080/21683565.2018.1499578

Rowhani, P., Lobel, D. B., Linderman, M., \& Ramankutty, N. (2011). Climate variability and crop production in Tanzania. Agricultural and Forest Meteorology, 151(4), 449-460. https://doi.org/10.1016/j.agrformet. 2010.12.002

Shekifu, C. Y. (2011). Improving Soil Productivity in Cassava Based Systems in the Coast Region of Tanzania: Phosphorus and Potassium Requirements under Monocropping and Intercropping (p. 14, A Thesis for award of PhD Degree at the Sokoine University of Agriculture, Morogoro, Tanzania).

Silici, L. (2014). Agro-ecology: What it is and what it has to offer (p. 28). IIED Issue Paper, London.

Tanzania National Census. (2012). Basic Demographic and Socio-Economic Profile Popular Version (p. 46, Key Findings 2012 PHC English Version).

TIC (Tanzania Investment Center). (2018). Cassava. Tanzania Investment Center. Retrieved from http://www.tanzaniainvest.com/Cassava

Udimal, T. B., Jincai, Z., Mensah, O. S., \& Caesar, A. E. (2017). Factors Influencing the Agricultural Technology Adoption: The Case of Improved Rice Varieties (Nerica) in the Northern Region, Ghana. Journal of Economics and Sustainable Development, 8,137-148

URT (United Republic of Tanzania). (2016). Agricultural Sector Development Programme (p. 88). Government Programme Document.

USDA (United States Department of Agriculture). (2015). Measuring Access to Food in Tanzania: A Food Basket Approach. Economic Information Bulletin, 135, 34.

Wannacott, T. H., \& Wannacott, R. J. (1990). Introductory Statistics (p. 736). Willey, Michigan State University.

Wanyama, R., Mathenge, M., \& Mbaka, Z. (2015). Agricultural Information Sources and their Effect on Farm productivity in Kenya (p. 4, Policy Brief No. 21).

Wezel, A., Belon, S. Dore, T., Francis, C., Vallod, D., \& David, C. (2009). Agroecology as a science, a movement and practice A review. Journal of Sustainable Agriculture, 2, 503-515. https://doi.org/10.1051/ agro/2009004

Wezel, A., Casagrande, M., Celette, F., Vian, J.-F., Ferrer, A., \& Peigné, J. (2013). Agroecological practices for sustainable agriculture. A review. Agronomy for Sustainable Development, 34(1), 1-20. https://doi.org/ 10.1126/science. 248.4954 .477

Williams, T. O. (1999). Factors influencing manure application by farmers in semi-arid west Africa. Nutrient Cycling in Agroecosystems, 55, 15-22. https://doi.org/10.1023/A:1009817323039

Yaseen, M., Xu, S., Yu, W., \& Hassan, S. (2016). Farmers' Access to Agricultural Information Sources: Evidences from Rural Pakistan. Journal of Agricultural Chemistry and Environment, 5, 12-19. https://doi.org/10.4236/jacen.2016.51B003 


\section{Copyrights}

Copyright for this article is retained by the author(s), with first publication rights granted to the journal.

This is an open-access article distributed under the terms and conditions of the Creative Commons Attribution license (http://creativecommons.org/licenses/by/4.0/). 